\title{
Seroprevalence of Canine Leishmaniasis in Northern Cyprus
}

\section{Kuzey Kıbrıs’ta Canine Leishmaniasis’in Prevalansı}

\author{
Tayfun Çanakçı ${ }^{1}$, Arif Kurtdede², Serdar Paşa ${ }^{3}$, Seray Töz Özensoy ${ }^{4}$, Yusuf Özbel ${ }^{4}$ \\ ${ }^{1}$ Clinic of PetZone, Nicosia, Northern Cyprus \\ 2Division of Clinical Sciences, Department of Internal Diseases, Ankara University School of Veterinary, Ankara, Turkey \\ ${ }^{3}$ Division of Clinical Sciences, Department of Internal Diseases, Adnan Menderes University School of Veterinary, Aydın, Turkey \\ ${ }^{4}$ Department of Parasitology, Ege University School of Medicine, Izmir, Turkey
}

\section{ABSTRACT}

Objective: Canine leishmaniasis (CanL) is an important public and veterinary health problem in Mediterranean Basin countries. In this study, we aimed to determine the seroprevalence of CanL in several provinces of Northern Cyprus.

Methods: The seroprevalence of CanL was determined by the indirect fluorescent antibody (IFA) test in dog sera. In total, 281 dogs were randomly selected from Nicosia $(n=80)$, Trikomo $(n=58)$, Famagusta $(n=60)$, Morphou $(n=30)$, and Kyrenia $(n=53)$, consistent with a statistically representative number of the regional dog population.

Results: Ten (3.55\%) out of 281 dogs were found to be seropositive by the IFA test. CanL seropositivity differed between cities as follows: $1.72 \%(1 / 58)$ in Trikomo, $13.20 \%$ (7/53) in Kyrenia, 1.67\% (1/60) in Famagusta, and 3.33\% (1/30) in Morphou. No seropositive dog was found in Nicosia. The symptoms in 37 out of 281 dogs were generalized lymphadenopathy, weight loss, alopecia, exfoliative dermatitis, and epistaxis. Four out of 10 seropositive dogs showed at least one clinical symptom that could be related with CanL.

Conclusion: CanL seroprevalence was found to be 3.55\% (10/281) in Northern Cyprus. Seropositive dogs, in particular, had lived in areas that exhibited rural as well as urban characteristics.

Keywords: Canine leishmaniasis, IFA test, seroprevalence, Northern Cyprus

Received: $18.04 .2016 \quad$ Accepted: 22.07.2016

\section{ÖZ}

Amaç: Canine leishmaniasis (CanL) Akdeniz havzasındaki ülkelerde önemli bir halk sağlığı ve veteriner sağlığı sorunudur. Bu çalışmada, Kuzey Kıbrıs'ın çeşitli illerinde CanL'in seroprevalansının belirlenmesi amaçlandı.

Yöntemler: CanL'nin prevalansı köpek serumlarında Indirekt Floresant Antikor (IFA) testi ile belirlendi. Çalışmada, istatistiksel temsil olarak her bölgedeki toplam köpek sayısı ile uyumlu olmak üzere Lefkoşa $(n=80)$, İskele $(n=58)$, Gazimağusa $(n=60)$, Güzelyurt ( $n=30)$ and Girne ( $n=53)$ şehirlerinden toplam 281 köpek rastgele seçildi.

Sonuçlar: IFA testi uygulanan 281 köpekten 10'unda (3,55\%) seropozitiflik saptandı. CanL enfeksiyonuna karşı seropozitiflik oranı şehirler arasında farklılık gösterdi. Seropozitiflik İskele'de \%1,72 (1/58), Girne'de \%13,20 (7/53), Gazimağusta'da \%1,67 (1/60) ve Güzelyurt'da \%3,33 (1/30) olarak belirlenirken Lefkoşa'da seropozitiflik saptanmadı. Çalışmadaki köpeklerden 37'sinde generalize lenfadenopati, ağırlık kaybı, alopesi, eksfoliatif dermatit ve burun kanaması belirlendi. Seropozitiflik saptanan 10 köpeğin 4'ünde CanL ile ilişkili klinik semptomlardan en az birinin var olduğu dikkati çekti.

Sonuç: Kuzey Kıbrıs'ta CanL seroprevalansı \%3,55 (10/281) olarak bulundu. Seropozitifliğin saptandığı 10 köpek kırsal ve kentsel özellikleri birlikte gösteren yörelerde yaşamaktaydı.

Anahtar kelimeler: Canine Leishmaniasis, IFAT, Kuzey Kıbrıs, seroprevalans

Geliş Tarihi: 18.04.2016

Kabul Tarihi: 22.07 .2016

\section{INTRODUCTION}

Leishmaniasis is a group of parasitic diseases caused by protozoa of the genus Leishmania in mammals. It leads to the development of various pathologies and clinical signs (1-3). Although leishmaniasis is found in many countries in the Mediterranean Basin (4), there are limited data on the prevalence and distribution of the disease and its impact on public health in Cyprus (5).

Foxes and dogs are the main natural reservoirs for several species of Leishmania spp. (6). The emergence of the dis-

Address for Correspondence / Yazışma Adresi: Dr. Serdar Paşa E.mail: pasaserdar@yahoo.co.uk DOI: 10.5152/tpd.2016.4807

(C) Copyright 2016 Turkish Society for Parasitology - Available online at www.tparazitolderg.org

CTelif hakkı 2016 Türkiye Parazitoloji Derneği - Makale metnine www.tparazitolderg.org web sayfasından ulaşılabilir. 
ease in the domestic dog population has become a problem in terms of human health (4, 7-9).

In a sero-epidemiological study conducted in southern Cyprus in 1996, anti-Leishmania antibodies were detected in dogs, and the parasite was defined as L. infantum zymodem MON 1 (5).

In Mediterranean countries, different from the new world, serological tests form the basis of epidemiological studies on the prevalence of canine leishmaniasis (CanL) (10). The prevalence of CanL differs between countries of the Mediterranean Basin (4). In a two-step study covering Southern Cyprus, the seroprevalence of CanL was found to be $1.7 \%$. A second study was conducted in residential areas intensively inhabited by CanL-seropositive dogs, and the seropositivity for CanL was found to be $10 \%$ (5). For the diagnosis of CanL, parasitological, serological, and molecular methods have been used (11).

In this study conducted in Northern Cyprus, we aimed to determine the seroprevalence of CanL using the indirect fluorescent antibody (IFA) test.

\section{METHODS}

This study was conducted between March and June 2007. The numbers of dogs that statistically represent each province were detected, and 281 blood samples were collected from randomly selected dogs of different breeds and genders who were aged from 7 months to 12 years and were living in the cities of Nicosia, Famagusta, Trikomo, Kyrenia, and Morphou, located in Northern Cyprus. The dogs chosen for this study were mainly (98.93\%) living outdoors.

Physical examination was performed for each dog, and signs, if any, were noted. In total, $5 \mathrm{~mL}$ of venous blood was collected from each dog by brachial vein puncture. The samples were stored at $+4^{\circ} \mathrm{C}$. Within 5 hours, the samples were centrifuged and sera were stored at $-20^{\circ} \mathrm{C}$ until use.

The antigen was prepared using the $L$. infantum MON 1 strain for the IFA test, and the test was performed as described previously. A twofold serial dilution (1:16 to 1:8192) of dog sera in PBS was used. A titer of $31: 128$ was considered positive for CanL $(12,13)$.

\section{Statistical analysis}

Descriptive statistical analyses were performed with SPSS 15.0 (SPSS Inc.; Chicago, IL, USA) packet program and the results were tabulated in Table 1. This study followed the ethical guidelines of animal subjects based on the Declaration of Helsinki.

\section{RESULTS}

In this study, the overall seroprevalence of CanL in Northern Cyprus was found to be $3.55 \%$ (10/281). The seroprevalence values differed in each city. Kyrenia showed the highest prevalence (13.20\%, 7/53), followed by Morphou (3.33\%, 1/30), Trikomo $(1.72 \%, 1 / 58)$, and Famagusta $(1.67 \%, 1 / 60)$. The seroprevalence of CanL according to cities and IFA test dilutions is shown in Table 1.

During clinical examination, 37 out of 281 dogs showed clinical signs such as lymphadenopathy, weight loss, alopecia, exfoliative dermatitis, and epistaxis that could be associated with CanL.
Table 1. Distribution of CanL-seropositive dogs according to provinces

\begin{tabular}{|l|c|c|cc|}
\hline & & & \multicolumn{2}{|c|}{ Seropositive dogs } \\
\hline Provinces & Coordinates & $\begin{array}{c}\text { The number of } \\
\text { sampled dogs }\end{array}$ & $\mathbf{n}$ & $\%$ \\
\hline Kyrenia & $\begin{array}{l}35.338892 \\
33.318705\end{array}$ & 53 & 7 & 13.2 \\
\hline Morphou & $\begin{array}{l}35.198544 \\
32.993746\end{array}$ & 30 & 1 & 3.3 \\
\hline Trikomo & $\begin{array}{l}35.286201 \\
33.892428\end{array}$ & 58 & 1 & 1.72 \\
\hline Famagusta & $\begin{array}{l}35.119157 \\
33.932905\end{array}$ & 60 & 1 & 1.67 \\
\hline Nicosia & $\begin{array}{l}35.201445 ; \\
33.351456\end{array}$ & 80 & 0 & 0 \\
\hline TOTAL & & 281 & 10 & 3.55 \\
\hline
\end{tabular}

Seropositivity was $10.81 \%$ (4/37) in dogs that had one or more clinical symptoms and $2.45 \%(6 / 244)$ in dogs that had no clinical symptoms.

\section{DISCUSSION}

Intense transmission of leishmaniasis by infected sand flies, from dog to dog or from dog to human, occurs in places where the Leishmania infection rate is very high in dogs (14). CanL is constantly seen in the entire Mediterranean Coast of Southern European countries, Bosnia and Herzegovina, Croatia, Malta, and Cyprus (15).

In European countries where CanL is endemic, the IFA test was used in 23 of 43 seroprevalence studies, conducted on between 1988 and 1999. The IFA test is considered as the "gold standard" for the serological diagnosis of CanL (10). Although CanL is endemic in countries bordering the Mediterranean Sea, the prevalence of the disease differs between countries and among regions within the same country (4). The prevalence of CanL in different regions of France has been reported to vary between $3.2 \%$ and $26.5 \%$. The overall disease prevalence in Greece is $6.8 \%$; it has been determined that this ratio rises to $48.4 \%$ in Athens. The prevalence of CanL has been reported to range from $1.4 \%$ to $22.2 \%$ in Italy and from $19.8 \%$ to $5.2 \%$ in Spain. The prevalence of CanL is $37.5 \%$ and $7 \%$ in Algeria and Egypt, respectively; it differs from $10 \%-21 \%$ in Israel and has been reported to be $30.9 \%$ in Malta $(4,16-17)$. The prevalence of CanL ranges from $1.6 \%$ to $28.26 \%$ in Turkey (18-21). In this study, the seroprevalence of CanL in five different cities was found to range from $1.7 \%$ to $13.2 \%$ and the overall seroprevalence was found to be $3.55 \%$. These results are similar to those presented in seroprevalence studies previously conducted in countries bordering the Mediterranean Sea.

In this study, the seroprevalence was found to be $13.2 \%$ in Kyrenia, 1.72\% in Trikomo, 1.67\% in Famagusta, and 3.3\% in Morphou; however, no seropositivity was observed among 80 samples collected from Nicosia. The rural characteristics of Kyrenia, Trikomo, 
Famagusta, and Morphou regions lead to more frequent contact with the vector sand flies of leishmaniasis and dogs. This case explains the higher rates of seropositivity of CanL in these areas in Northern Cyprus. The urban characteristics and geographic features, spraying of insecticides by municipalities, and absence of possible disease vectors in Nicosia should be taken into consideration when discussing the lack of disease prevalence in the area. In a study conducted in Northern Cyprus, the prevalence of CanL among 83 dogs, mainly from Kyrenia and Nicosia provinces, was found to be $3.61 \%$ by IFAT (13). In the first phase of the study published in Southern Cyprus, the seroprevalence in randomly selected blood samples collected from 601 dogs was found to be $1.7 \%$. In the second phase of this study, 301 blood samples were taken from residential areas intensively inhabited by CanL-seropositive dogs, and the seroprevalence of CanL in these regions was $10 \%$ (5). The present study conducted in Northern Cyprus is similar to the first phase of the study conducted in Southern Cyprus in terms of the method. Overall seroprevalence of CanL in Northern Cyprus was higher than the overall seroprevalence determined in Southern Cyprus. The geographical and demographic characteristics of Northern Cyprus are more suitable for the incidence of the disease than those of Southern Cyprus for the development of CanL. This case may explain the causes of the higher seroprevalence of CanL in Northern Cyprus. A large proportion of dogs with CanL do not show any clinical signs (10, 20,22 ). Similar to those findings, in this study, only four out of 10 seropositive dogs (40\%) showed one or more clinical symptoms that could be associated with CanL.

Serological analysis of samples showed that the seroprevalence of CanL is $3.55 \%$ in Northern Cyprus. CanL is more common in peridomestic areas in Northern Cyprus.

From a geographical point of view, the seroprevalence of CanL in the northern part of Five Finger Mountains is four to seven times higher than that in the southern part. Thus, while planning researches and making disease prevention programs, the geographical distribution of CanL in Northern Cyprus should be taken into consideration.

\section{CONCLUSION}

The seroprevalence of CanL was found to be 3.55\% (10/281) in Northern Cyprus.

Seropositive dogs, in particular, had lived in areas that exhibited rural as well as urban characteristics.

Ethics Committee Approval: Authors declared that the research was conducted according to the principles of the World Medical Association Declaration of Helsinki "Ethical Principles for Medical Research Involving Human Subjects", (amended in October 2013).

Informed Consent: Not required in this study.

Peer-review: Externally peer-reviewed.

Author Contributions: Concept - A.K., T.Ç., S.P.; Design - T.Ç., A.K., S.P., S.T.Ö., Y.Ö.; Supervision - A.K.; Data Collection and/or Processing - T.Ç., S.T.Ö., Y.Ö.; Analysis and/or Interpretation - T.Ç., A.K., S.P., S.T.Ö., Y.Ö.; Literature Review - A.K., T.Ç., S.P.; Writing - T.Ç., A.K.; Critical Review S.P., S.T.Ö., Y.Ö.
Conflict of Interest: No conflict of interest was declared by the authors.

Financial Disclosure: The authors declared that this study has received no financial support.

Etik Komite Onayı: Yazarlar çalışmanın World Medical Association Declaration of Helsinki "Ethical Principles for Medical Research Involving Human Subjects", (amended in October 2013) prensiplerine uygun olarak yapıldığını beyan etmişlerdir.

Hasta Onamı: Bu çalışma için hasta onamına gerek yoktur.

Yazar Katkıları: Fikir - A.K.,T.Ç., S.P.; Tasarım - T.Ç., A.K., S.P., S.T.Ö., Y.Ö.; Denetleme - A.K.; Veri Toplanması ve/veya İşlemesi - T.Ç., S.T.Ö., Y.Ö.; Analiz ve/veya Yorum - T.Ç., A.K., S.P., S.T.Ö., Y.Ö.; Literatür Taraması A.K., T.Ç., S.P.; Yazıyı Yazan - T.Ç., A.K.; Eleştirel Inceleme - S.P., S.T.Ö., Y.Ö

Çıkar Çatışması: Yazarlar çıkar çatışması bildirmemişlerdir.

Finansal Destek: Yazarlar bu çalışma için finansal destek almadıklarını beyan etmişlerdir.

\section{REFERENCES}

1. Kontos V. Zoonoses in the Mediterranean Area 2002. (cited 2006 June 6). Available from: URL: http//www.vin.com.

2. Toplu N, Aydoğan A. An immunohistochemical study in cases with usual and unusual clinicopathological findings of canine visceral leishmaniosis. Parasitol Res 2011; 109: 1051-7. [CrossRef]

3. Freitas JC, Lopes-Neto BE, Abreu CR, Coura-Vital W, Braga SL, Reis $A B$, Nunes-Pinheiro DC. Profile of anti-Leishmania antibodies related to clinical picture in canine visceral leishmaniasis. Res Vet Sci 2012; 93: 705-9. [CrossRef]

4. Dereure J, Pratlong F, Dedet JP. Geographical distribution and the identification of parasites causing canine leishmaniasis in the Mediterranean Basin. Proceedings of the International Canine Leishmaniasis Forum; Barcelona-Spain: 1999. p. 18-25.

5. Deplazes P, Grimm F, Papaprodromou M, Cavaliero T, Gramiccia M, Christofi G, Christofi N, Economides P, Eckert J. Canine leishmaniasis in Cyprus due to Leishmania infantum MON 1. Acta Trop 1998; 71: 169-78. [CrossRef]

6. Hommel M. Visceral Leishmaniasis: Biology of Parasite. Journal of Infection 1999; 39: 101-11. [CrossRef]

7. Koutınas AF, Polizopoulou ZS, Saridomichelakis MN, Argyriadis D, Fytianou A, Plevraki KG. Clinical considerations on canine visceral leishmaniasis in Greece: a retrospective study of 158 cases (19891996). J Am Anim Hosp Assoc 1999; 35: 376-83. [CrossRef]

8. Straus-Ayali D, Baneth G. Canine visceral leishmanisasis. Recent advances in canine infectious diseases. International Veterinary Information Service 2001 (cited 2006 April 21). Available from: URL: http://www.ivis.org.

9. Pennisi MG. A high prevalence of feline leishmaniasis in southern Italy. Proceedings of the Second International Canine Leishmaniasis Forum; Sevilla,-Spain: 2002. p. 39-48.

10. Gradoni L. The diagnosis of canine leishmaniasis. Canine Leishmaniasis: moving towards a solution. Proceedings of the Second International Canine Leishmaniasis Forum; Sevilla-Spain: 2002. p. 7-14.

11. Ferrer LM. Clinical aspects of canine leishmaniasis, Canine Leishmaniasis: an update. Proceedings of the International Canine Leishmaniasis Forum; Barcelona-Spain: 1999. p. 6-11.

12. Abranches P, Silva-Pereria MC, Conceicao-Silva FM, Santos-Gomes GM, Janz JG. Canine leishmaniasis: pathological and ecological factors influencing transmission of infection. Journal of Parasitology 1991; 77: 557-61. [CrossRef] 
13. Özensoy Töz S, Ertabaklar H, Göçmen B, Demir S, Karakuş M, Arserim SK, Balcıoğlu iC, Çanakçı T, Özbel Y. An epidemiological study on canine leishmaniasis and sand flies in Northern Cyprus. Turkiye Parazitol Derg 2013; 37: 107-12.

14. Vercammen F, Berkvens D, Le Ray D, Jacquet D, Vervoort T. Development of a slide ELISA for canine leishmaniasis and comparison with four serological tests. Vet Record 1997; 141: 328-30. [CrossRef]

15. Ciaramella P, Oliva G, Luna RD, Gradoni L, Ambrosio R, Cortese L, Scalone A, Persechino A. A retrospective clinical study of canine leishmaniasis in 150 dogs naturally infected by Leishmania infantum. Vet Record 1997; 141: 539-43. [CrossRef]

16. Gradoni L. Epizootiology of canine leishmaniasis in southern Europe. Canine Leishmaniasis: an update. Proceedings of the International Canine Leishmaniasis Forum; Barcelona- Spain: 1999. p. 32-39.

17. Baneth G, Dank G, Keren-Kornblatt E, Sekeles E, Adini I, Eisenberger $\mathrm{CL}$, et al. Emergence of visceral leishmaniasis in central Israil. Am J Trop Med Hyg 1998; 59: 722-55.
18. Özbel Y, Turgay N, Özensoy S, Özbilgin A, Alkan MZ, Özcel MA, et al. Epidemiology, diagnosis and control of leishmaniasis in the Mediterranean region. Ann Trop Med Parasitol 1995; 89: 89-93. [CrossRef]

19. Coşkun Ş, Batmaz H, Aydın L, Yılmaz F. Seroprevalance of Leishmania infantum infection of dogs in the western part of Turkey. Turkiye Parazitol Derg 1997; 21: 287-91.

20. Voyvoda H, Paşa S, Özensoy TS, Özbel Y, Ertabaklar H. Aydın'ın bazı ilçe ve köyleri ile İzmir'in Selçuk ilçesindeki köpeklerde Leishmaniasis ve Drofilariasis'in prevalansı. Turk J Vet Anim Sci 2004; 28: 110511.

21. Ertabaklar H, Özensoy TS, Taylan OA, Rastgeldi S, Balcıoğlu iC, Özbel Y. Serological and entomological survey in a zoonotic visceral leishmaniasis focus of North Central Anatolia, Turkey, Çorum province. Acta Trop 2005; 25: 128-31. [CrossRef]

22. Özensoy ST, Özbel Y, Ertabaklar H, Yıldızlı N, Korkmaz M, Alkan MZ. Comparisons of clinical findings and serological data in the diagnossis of canine visceral leishmaniasis. Turk J Vet Anim Sci 2005; 29: 269-73. 